\title{
The Anorexigenic Neural Pathways of Oxytocin and Their Clinical Implication
}

\author{
Yuko Maejima $^{\mathrm{a}}$ Shoko Yokota $^{\mathrm{a}}$ Katsuhiko Nishimori ${ }^{\mathrm{b}}$ Kenju Shimomura ${ }^{\mathrm{a}}$ \\ ${ }^{a}$ Department of Bioregulation and Pharmacological Medicine, Fukushima Medical University School of \\ Medicine, Fukushima, Japan; ${ }^{b}$ Department of Molecular and Cell Biology, Graduate School of Agricultural Science, \\ Tohoku University, Sendai, Japan
}

\section{Keywords}

Oxytocin · Neurons $\cdot$ Hypothalamus $\cdot$ Brain stem $\cdot$ Clinical implications · Obesity

\begin{abstract}
Oxytocin was discovered in 1906 as a peptide that promotes delivery and milk ejection; however, its additional physiological functions were determined 100 years later. Many recent articles have reported newly discovered effects of oxytocin on social communication, bonding, reward-related behavior, adipose tissue, and muscle and food intake regulation. Because oxytocin neurons project to various regions in the brain that contribute to both feeding reward (hedonic feeding) and the regulation of energy balance (homeostatic feeding), the mechanisms of oxytocin on food intake regulation are complicated and largely unknown. Oxytocin neurons in the paraventricular nucleus (PVN) receive neural projections from the arcuate nucleus (ARC), which is an important center for feeding regulation. On the other hand, these neurons in the PVN and supraoptic nucleus project to the ARC. PVN oxytocin neurons also project to the brain stem and the reward-related limbic system. In addition to this, oxytocin induces lipolysis and decreases fat mass. However,
\end{abstract}

these effects in feeding and adipose tissue are known to be dependent on body weight (BW). Oxytocin treatment is more effective in food intake regulation and fat mass decline for individuals with leptin resistance and higher BW, but is known to be less effective in individuals with normal BW. In this review, we present in detail the recent findings on the physiological role of oxytocin in feeding regulation and the anorexigenic neural pathway of oxytocin neurons, as well as the advantage of oxytocin usage for anti-obesity treatment.

(c) 2018 S. Karger AG, Basel

\section{Introduction}

Oxytocin is a neuropeptide composed of 9 amino acids, and its sequence and structure are very similar to arginine vasopressin. It is produced in the hypothalamus and is released to other regions of the central nervous system (CNS) or the circulatory system throughout the body via the posterior pituitary gland. This neuropeptide was discovered by Sir Henry Dale in 1906 and named "oxytocin" (meaning "swift birth" in Greek), because of its ability to contract the uterus of a pregnant cat [1]. In 1953, oxytocin became the first polypeptide hormone to

\section{KARGER}

(c) 2018 S. Karger AG, Basel

E-Mail karger@karger.com

www.karger.com/nen
Yuko Maejima

Department of Bioregulation and Pharmacological Medicine

Fukushima Medical University

1 Hikarigaoka, Fukushima (Japan)

E-Mail maejimay@fmu.ac.jp 


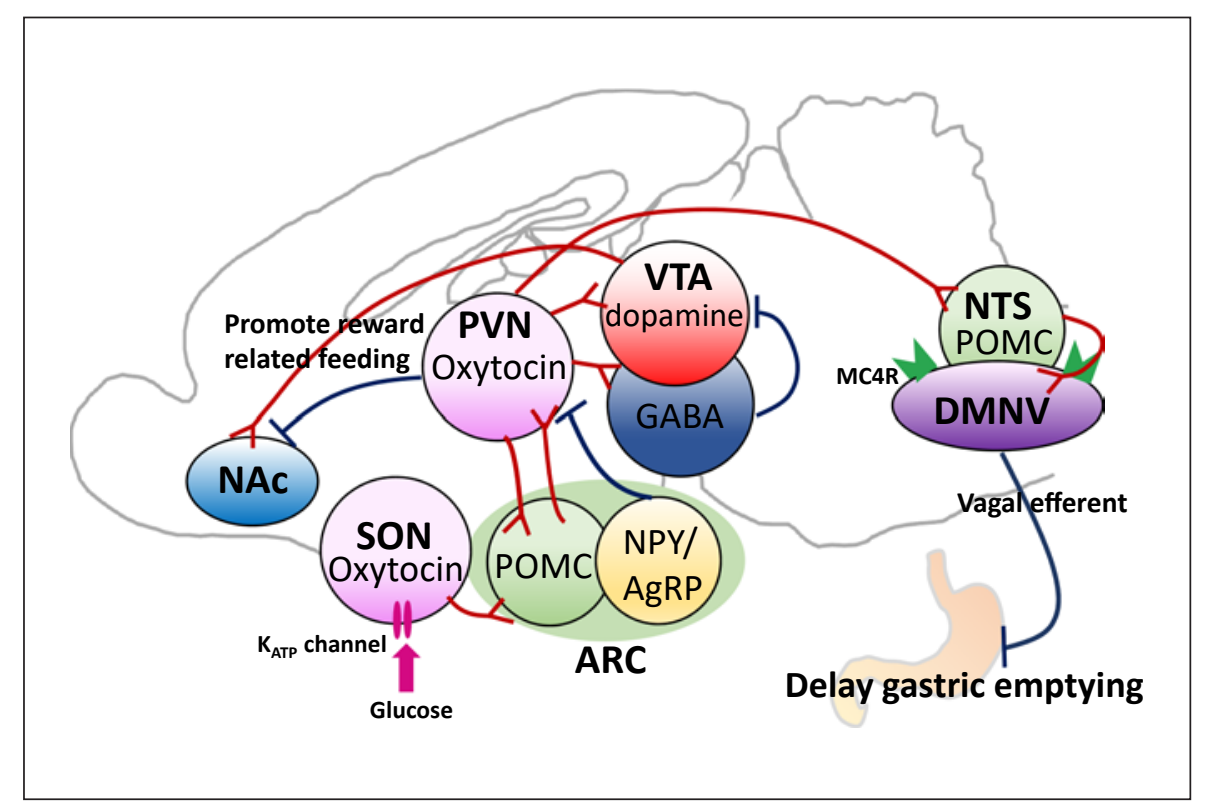

Fig. 1. Proposed model for oxytocin-related neural pathways that regulate food intake. The red arrows indicate the stimulatory projections and the blue arrows indicate the inhibitory projections. Oxytocin neurons in the PVN and SON activate POMC neurons in the ARC. Oxytocin neurons in the PVN are subsequently activated by the POMC neuron-derived $\alpha-\mathrm{MSH}$. Oxytocin neurons in the SON express the $\mathrm{K}_{\mathrm{ATP}}$ channel and play a role as a glucose sensor and, thus, activate POMC neurons in the ARC. NPY/AgRP neurons project to the PVN oxytocin neurons and suppress their neural activity. PVN oxytocin neurons project to the POMC neurons in the NTS. Melanocortin receptors are expressed in the
DMNV, which is the first nucleus of the vagal afferent, and receive projection from neighboring NTS POMC neurons. The DMNV regulates the gastrointestinal system, and delays gastric emptying. In reward-related feeding, oxytocin neurons in the $\mathrm{PVN}$ project to the dopamine- and GABA-containing neurons in the VTA, and activate VTA neurons. GABA neurons in the VTA regulate the activity of the dopamine neurons. VTA dopamine neurons project to the NAc to activate the neurons in the NAc and promote reward-related feeding. However, PVN oxytocin suppresses these neurons and decreases reward-related feeding. be sequenced and synthesized, and Vincent du Vigneaud [2] was awarded the Nobel Prize for this achievement. From an evolutionary point of view, the origin of oxytocin is considered to date back nearly 600 million years, and oxytocin-like peptides/homologues can be found across almost the entire animal kingdom, from insects to mammals [3].

Oxytocin is synthesized in the paraventricular nucleus (PVN) and supraoptic nucleus (SON). The magnocellular oxytocin neurons in the PVN and SON project to the posterior pituitary gland and secrete oxytocin into the periphery circulation system [4]. On the other hand, parvocellular oxytocin neurons in the PVN project to and secrete oxytocin into the CNS, although recent data indicate that oxytocin neurons in the SON may also secrete oxytocin into the CNS $[5,6]$.

The physiological function of oxytocin was originally known for promoting delivery and milk ejection in mammalian females. However, recent studies have discovered its new physiological functions, which include increased trust in humans $[7,8]$, change of paternal and maternal behavior toward their children [9-11], increase in pair bonding $[12,13]$, and an increased ability to understand other people's feelings or improvement of social communication [14-16]. In addition, there are many articles related to the role of oxytocin in psychiatric diseases [17-20].

Another important new discovery of oxytocin's function is food intake and body weight (BW) regulation. The effect of oxytocin on food intake is generally considered to be regulated mainly by the oxytocin secreted within the CNS and not through the peripherally secreted oxytocin [21]. The first report on the anorexigenic effect of oxytocin after acute intraperitoneal (IP) and intracerebroventricular (ICV) injection was reported in 1989 [22]. Oxytocin injection, either ICV, IP or subcutaneous, was found to decrease food intake in mice [23-26], rats [22-33], and monkeys [34]. Nasal treatment of oxytocin was also reported to decrease food intake in both mice and humans $[24,35,36]$. 
However, this reduction of BW is not only induced by food intake reduction; oxytocin also induces lipolysis in adipose tissue and decreases fat mass [29, 34, 37-40]. Recent studies have clarified the various new mechanisms of oxytocin's anorexigenic effects through the CNS and promotion of catabolic reactions on peripheral tissues. Although its precise mechanism remains to be elucidated, oxytocin's possible anorexigenic pathways are summarized in Figure 1. This review will focus on both the physiological properties of oxytocin in the CNS and the advantage of oxytocin usage for anti-obesity treatment.

\section{Physiological Role of Oxytocin in Feeding Regulation}

Oxytocin plays an important role in the termination of food intake, and oxytocin neurons are activated following food consumption or ingestion [41, 42]. Hypothalamic oxytocin mRNA expression is reduced with fasting and recovers with refeeding [43] or the administration of leptin [44]. Also, the suppression of exocytosis of oxytocin, or genetic reduction of oxytocin expression, increases food intake $[25,43]$, and ablation of oxytocin neurons increases BW gain by decreasing energy expenditure in male mice fed a high fat diet (HFD) [45]. The ablation of the neurons that express oxytocin receptors, or knock down of oxytocin receptor expression in the nucleus of the solitary tract (NTS) induces hyperphagia [46, 47]. In addition to NTS, oxytocin receptor activation in the arcuate nucleus (ARC) rapidly causes satiety [48]. These reports suggest that the oxytocin neurons physiologically regulate food intake responding to fasting and satiety conditions.

Furthermore, rodents generally show a circadian rhythm in feeding patterns, such as suppression of feeding in the light phase and increased feeding in the dark phase. The secretion of oxytocin also shows a circadian rhythmic pattern with a rise of circulating oxytocin level during the day [26], which was confirmed by measuring secreted oxytocin from a brain slice including the PVN where oxytocin positive neurons mainly reside [49]. In another study, ICV injection of an oxytocin antagonist increased food intake more effectively in the light phase relative to the dark phase [26]. Taking the above oxytocin effects into consideration, endogenously secreted oxytocin may play a role in suppressing food intake during the light phase in rodents. It is possible that one of the physiological roles of central oxytocin is to develop a circadian rhythmic feeding pattern.

On the other hand, there are several reports indicating that endogenous oxytocin has no effect on regulating feeding behavior. There are reports on oxytocin receptor-defi-

Anorexigenic Oxytocin and Clinical Implications cient mice showing no difference in food intake [50] or specific distribution of the oxytocin neurons in the PVN revealing no change in food intake when measured on a normal chow diet [45]. However, these reports may also indicate the existence of mechanisms that can compensate for the absence of oxytocin receptor signaling. In addition, oxytocin receptor-deficient mice showed late-onset obesity and reduced thermogenesis [50], and the mice with specific ablation of oxytocin neurons exhibited increased BW under HFD conditions followed by decreased energy expenditure [45]. These reports suggest that oxytocin receptor signaling may also be involved in energy expenditure regulation, as well as feeding regulation.

\section{The Interaction between Oxytocin Neurons, ARC Feeding-Associated Peptides and Gut Secretory Hormones}

W. Bargman and E. Scharrer reported in the early 1950s that oxytocin is mainly synthesized in the PVN and SON of the hypothalamus. Neurons in the PVN contain various anorexigenic neuropeptides including thyrotropin-releasing hormone (TRH), corticotrophin-releasing hormone (CRH) [51], nesfatin-1 [52, 53], and brain-derived neurotrophic factor [54], as well as oxytocin [6].

The PVN receives abundant projections from the ARC [55]. There are two opposite types of neurons regulating feeding behavior distributed in the ARC [51]: neurons containing proopiomelanocortin/cocaine- and amphetamine-regulated transcript (POMC/CART); and neurons containing neuropeptide-Y/agouti-related peptide (NPY/AgRP) [51, 56].

POMC is a precursor of several peptides including a-melanocyte-stimulating hormone (a-MSH) [57]. a$\mathrm{MSH}$ is a strong anorexigenic peptide, and its receptor, melanocortin $3 / 4$ receptor $(\mathrm{MC} 3 / 4 \mathrm{R})$, is distributed in numerous nuclei including the PVN [58]. MC4R deficiency promotes hyperphagia and obesity in both mice and humans $[59,60]$.

On the other hand, NPY is a strong orexigenic peptide [61], and its ICV injection or specific activation of its neurons [62] promotes feeding behavior. NPY suppresses the activities of neurons containing various anorexigenic neuropeptides in the PVN, and therefore promotes food intake. However, AgRP, another neuropeptide that resides together with NPY, is the antagonist of MC3/4R and prevents $\alpha$-MSH from binding to MC4R-expressing PVN neurons, which suppresses the activation of PVN neurons and promotes feeding behavior [63].

Neuroendocrinology 2018;107:91-104 DOI: $10.1159 / 000489263$ 
Originally, neurons in the ARC were known as the first-order neurons [51]. This is because the tight junction of the blood brain barrier in this area is looser than the other brain regions, and easily receives and senses the peripheral condition through factors in the blood stream such as leptin, ghrelin, glucose, etc. [64]. The peripheral hormonal information received in the first-order neurons in ARC is conveyed to the second-order neurons including the PVN. It has been considered that the processing from first-order neurons to second-order neurons induces orexigenic/anorexigenic behavior.

\section{Oxytocin and ARC POMC}

Concerning the relation between POMC neurons in the ARC and oxytocin neurons in the PVN, it is considered that $\alpha-\mathrm{MSH}$ derived from POMC neurons activates PVN magnocellular oxytocin neurons [65] and increases secretion of oxytocin from the PVN [49]. MC4R mRNA is most abundantly distributed in the PVN in both humans and rodents [66] and MC4R expression was confirmed in some, if not all, of the oxytocin neurons in the PVN [67]. Central or local PVN administration of $\alpha-\mathrm{MSH}$ or its ligands powerfully inhibits food intake [68], and induces c-fos expression in the PVN oxytocin neurons [69]. The majority of c-fos positive PVN neurons, which express $\mathrm{c}-$ fos after fasting and refeeding, are contacted by terminals of POMC-immunoreactive neurons [70]. The anorexic effect induced by the central administration of a-MSH can be attenuated by oxytocin antagonist pretreatment [71], indicating the involvement of oxytocin on a-MSH-mediated food intake regulation. Our study also confirmed a significant increase in oxytocin secretion when $10^{-8} \mathrm{M} \alpha$-MSH was applied to a brain slice containing rat PVN [49]. These reports and our data indicate the physiological importance of the projection of ARC POMC neurons (first order) to the PVN oxytocin neurons (second order) in the regulation of feeding.

\section{Oxytocin and ARC NPY/AgRP}

On the other hand, the NPY/AgRP neurons in the ARC also affect activities of PVN oxytocin neurons and food intake. By using optogenetics technology, Atasoy et al. [72] demonstrated that AgRP neurons in the ARC induce feeding via inhibition of oxytocin neurons. In the report, the activation of AgRP neurons increased food intake, while the simultaneous activation of both AgRP and PVN oxytocin neurons had no effect on food intake. Furthermore, AgRP activation-induced feeding was almost blunted by local injection of the NPY Y1 receptor or GABA receptor antagonist into the PVN [72]. These results indi- cate that both the NPY Y1 receptors and $\mathrm{GABA}_{\mathrm{A}}$ receptors are essential for the anorexigenic effect in the PVN.

As for the NPY, both Y1 and Y5 receptors are distributed in the PVN [73], and NPY fibers project to the PVN, indicating that NPY Y1 and Y5 receptor subtypes mediate NPY's action in feeding regulation in the CNS. These reports also emphasize the physiological importance of the projection from POMC and NPY/AgRP neurons (first order) to the PVN oxytocin neurons (second order) in the regulation of feeding.

\section{Oxytocin and Gut-Secreted Hormone}

Another important neural pathway that stimulates oxytocin neurons in the hypothalamus is the vagal afferent-NTS pathway. NTS contains key nuclei that respond to meal-related signals that enter the brain from the periphery via the vagal afferent [74]. It is known that insulin and gut-secreted hormones such as CCK and GLP-1 activate the vagal afferent pathway [75-77]. The vagal afferent senses these gut-secreted peptides and inputs this information into the NTS neurons, which receive abundant projections from PVN oxytocin neurons $[78,79]$. IP injection of CCK induces $\mathrm{c}$-fos expression in the brainstem and PVN, where oxytocin neurons are selectively activated $[80,81]$. Chemogenetic activation of NTS neurons elicit c-fos-positive neurons in the PVN and reduce food intake and BW in mice [82]. Taking these reports into consideration, postprandial secretion of the gut hormone contributes to suppressing appetite by mediating the vagal afferent NTS-PVN oxytocin neurons.

The next question would be regarding the mechanism for the oxytocin neurons in the PVN to affect food intake. We have shown in the past that the anorexigenic effect of central oxytocin administration can be abolished by pretreatment with melanocortin receptor blockers [53]. This may indicate that oxytocin induces an anorexigenic effect via POMC neurons, which are distributed in the ARC and NTS in the CNS. In other words, PVN oxytocin neurons and POMC neurons in the ARC and NTS may reciprocally regulate one another. We will discuss the mechanism of oxytocin-induced food intake regulation through patterns of subsequent projections from PVN oxytocin neurons in the following sections.

\section{The Effectors of Anorexigenic Oxytocin Pathway}

\section{PVN Oxytocin Neurons $\rightarrow$ NTS POMC Neurons}

Although the number of POMC neurons is less in the NTS compared to the ARC, POMC neurons in the NTS 
are considered to play an important role in feeding regulation. Zhan et al. [83] demonstrated that POMC neurons in the NTS regulate acute feeding suppression. In contrast, POMC neurons in the ARC regulate long-term suppression of feeding behavior. NTS POMC neurons are known to be stimulated by gut hormones via the vagal afferent pathway $[84,85]$.

There are several reports showing the projection of the PVN neurons to the brain stem or spinal cord [70, $86,87]$. Both oxytocin and vasopressin neurons in the PVN project to the spinal cord and/or the dorsal vagal complex. The stem contains area postrema, NTS, and the dorsal motor nucleus of the vagus (DMNV) [86]. Application of oxytocin into the 4 th ventricle or microinjection into the NTS in rats reduces food intake $[33,88]$. Endogenous oxytocin receptor signaling in the NTS mediates food intake-inhibitory effects [47]. In addition, oxytocin immunoreactive varicosities closely appose or contact tyrosine hydroxylase immunoreactive neurons [89] and POMC neurons [53] in the NTS. The neurons in the NTS project to the adjacent DMNV [90], and gastric motility is inhibited by the microinjection of oxytocin into the DMNV [91]. Oxytocin receptors are abundantly distributed in the NTS and DMNV [92], which regulates gastric motility via the noncholinergic inhibitory or cholinergic pathway [90]. Leptin-responsive oxytocin neurons project to the caudal brain stem and reduce food intake [87]; however, oxytocin receptors in the hindbrain are also known to react to circulating oxytocin and contribute to food intake regulation [88]. These reports suggest the importance of oxytocin in feeding regulation via dorsal vagal complex-regulated gastric motility.

\section{PVN Oxytocin Neurons $\rightarrow$ ARC POMC Neurons}

There is evidence that oxytocin decreases food intake via the hypothalamic ARC. Oxytocin receptors are distributed throughout the ARC with nearly $50 \%$ of oxytocin receptor-positive neurons being POMC neurons, and intra-ARC injection of oxytocin decreases food intake [6]. In addition, we detected the oxytocin axon terminals contacting the ARC POMC neurons [6] and the single POMC neurons isolated from the ARC were activated by the application of oxytocin [6]. According to the results obtained from experiments using a retrograde tracer, nearly $30 \%$ of oxytocin neurons in the PVN (a majority being the medial parvocellular oxytocin neurons) were found to project to the ARC [6]. Surprisingly, nearly $20 \%$ of oxytocin neurons in the SON were also found to project to the ARC [6]. The projection from the PVN to the ARC is the reciprocal projection from the classical projection model, i.e., the anorectic pathway from oxytocin neurons in the PVN (classically second-order neurons) to POMC neurons (classically first-order neurons) in the ARC. Csiffáry et al. [93] also demonstrated using an electron microscope that the PVN oxytocin neurons project to the neurons expressing $\beta$-endorphin in ARC, which were derived from POMC.

There are several reports demonstrating the importance of the reciprocal process from second-order to firstorder neurons [94]. Krashes et al. [94] reported that the TRH and pituitary adenylate cyclase-activating polypeptide (PACAP) from the PVN induce a marked activation of AgRP neurons in the ARC and stimulate intense feeding in mice. The study also demonstrated marked fidelity in the reciprocal TRH/PACAP PVN glutamatergic $\rightarrow$ AgRP ARC GABAergic $\rightarrow$ satiety PVN neuron circuit that drives feeding. These reports showing the neural pathway from the PVN $\rightarrow$ ARC (i.e., the reciprocal process from second-order to first-order neurons) are a new concept in the study of feeding regulation, and the concept of one-way regulation of "first order neurons $\rightarrow$ second order neurons" must be reconsidered for further study to elucidate the central mechanism of feeding regulation.

Although the physiological relevance of these neural pathways (ARC $\rightarrow$ PVN or PVN $\rightarrow$ ARC) is unclear, it can be considered that the neural pathway of the PVN $\rightarrow$ ARC may function as a downstream relay of the vagal afferent-NTS pathway. This is supported by reports showing that NTS neurons receive abundant projections from PVN oxytocin neurons $[78,79]$. On the other hand, the ARC $\rightarrow$ PVN pathway may be under the influence of peripheral humoral factors, such as leptin, which can penetrate the blood brain barrier. Further studies are required to clarify the physiological role of these neural pathways.

Our recent study also found that a single PVN neuron projects to both the medial part of the ARC and the NTS with axon collateral projection [95]. It is speculated that the PVN neurons with axon collateral projection can stimulate different brain regions (ARC and NTS) at the same time. We identified that these PVN neurons with axon collateral projection to the ARC and the NTS are composed of NUCB2/nesfatin-1-containing neurons. It is reported that nearly $80 \%$ of NUCB $2 /$ nesfatin- 1 neurons also contain oxytocin [96]. Thus, we examined the relationship between oxytocin in PVN neurons and axon collateral projection to the ARC and NTS. Interestingly, these neurons with axon collateral projection also contain oxy- 
tocin (data not shown). Further studies on the physiological role of the neurons with axon collateral projection to the ARC and NTS in feeding regulation are required.

\section{PVN Oxytocin Neurons $\rightarrow$ Reward-Related Brain}

Regions

The limbic system is known to play a role in the regulation of instinct, emotion, and reward-related behavior. With regard to reward-related feeding behavior, projection from the ventral tegmental area (VTA) to the nucleus accumbens (NAc) plays a critical role in the process $[97,98]$.

Numerous dopamine neurons are distributed in the VTA [99], and the neural pathway from VTA dopamine neurons to NAc is related to drug addiction [100]. It is considered that binge eating is also an addiction to palatable food [101]. Eating a palatable meal is known to activate dopamine neurons in the VTA and NAc [102]. This dopamine input induces a pleasant feeling and stimulates craving for binge eating [103].

Several recent articles reported the effect of oxytocin on reward-related function and addiction. In those studies, oxytocin treatment attenuated the consumption of fructose-sweetened beverages in monkeys [34], addictive cocaine-seeking behavior in rats [104], and intra-VTA injection of oxytocin reduced sucrose intake in rats [105, 106]. Also, oxytocin knockout mice showed an enhancement for palatable sucrose intake [107]. In addition to these reports, it was also confirmed that oxytocin reduces reward-driven food intake, such as a reduction of highly palatable chocolate cookie consumption in humans [108].

PVN oxytocin neurons project to the VTA dopamine neurons [109] and activate dopamine and GABA neurons within the VTA [109]. This therefore suggests that oxytocin modulates the balance of dopamine neurons [109]. On the other hand, oxytocin receptors are expressed in NAc, the site where dopamine neurons project from the VTA. Furthermore, oxytocin administration to NAc reduces food, palatable sucrose and saccharin intake [110], as well as attenuates methamphetamine seeking and demand [111]. In social rewards, coordinated activity of oxytocin and serotonin in NAc is required [112]. The interaction between dopamine, serotonin and oxytocin in reward-related behavior is complex and poorly understood. However, it is suggested that the action of oxytocin in NAc may play an important role in such behavior.

\section{The Regulation of SON Oxytocin Neurons}

There are many reports showing c-fos expression in SON neurons after feeding $[41,113,114]$. Numerous neuropeptides are reported to reside in this nucleus, such as vasopressin, oxytocin, urocortin, NUCB2/nesfatin-1 etc. $[96,113,115,116]$. SON is composed of magnocellular neurons that project to the posterior pituitary resulting in secretion of oxytocin into the periphery. Activity of SON oxytocin neurons is regulated by hypertonic solution [117], serotonin, noradrenalin [118], glucose [119], and $\alpha-\mathrm{MSH}$ [120]. $\alpha-\mathrm{MSH}$ inhibits the electrical activity of oxytocin neurons and inhibits secretion from its nerve ending but induces dendritic oxytocin release independently from its neuron activity [120]. The neurons in the $\mathrm{SON}$ receive the projection from the suprachiasmatic nucleus, and it may regulate daily changes in neurohypophysial hormone secretion [121]. Also, it receives projections from the subfornical organ (SFO), and neurons in the SFO regulate excitability of both vasopressinergic and oxytocinergic neurosecretory cells for the regulation of body water balance [122]. Our histological study demonstrated the clear projection of SON oxytocin neurons to the ARC [6] suggesting that the oxytocin neurons in the $\mathrm{SON}$ regulate the activities of ARC neurons. The detailed relation between oxytocin neurons in the SON and ARC neurons remains unclear. Although there is little reference, the reports mentioned above suggest that SON oxytocin neurons may be involved in circadian- and osmolality-related feeding regulation.

Another factor that may contribute to food intake regulation for SON oxytocin neurons is glucose sensing. In SON oxytocin neurons, it is considered that insulin activates phosphatidylinositol 3 kinase (PI3K), which induces the translocation of glucose transporter (GLUT) 4 into the membrane [119]. Although GLUT3 is already present in the SON neuron membrane, this additional membrane translocation of GLUT4 induces further glucose uptake and glucokinase-mediated glycolysis as well as ATP production [119]. This rise in intracellular ATP promotes inhibition of ATP sensitive $\mathrm{K}^{+}\left(\mathrm{K}_{\mathrm{ATP}}\right)$ channels, which express in SON oxytocin neurons (Fig. 2), and induce membrane depolarization and action potential firing, ultimately leading to oxytocin release [119]. This model could indicate that SON oxytocin neurons may function as glucose/metabolic sensors and participate in food intake regulation; however, further study is required.

\section{Clinical Implications of Oxytocin}

Currently, oxytocin is considered as a potential neuropeptide to improve social communication $[123,124]$, the ability to understand other people's feeling [14], autism
96

Neuroendocrinology 2018;107:91-104 DOI: $10.1159 / 000489263$
Maejima/Yokota/Nishimori/Shimomura 

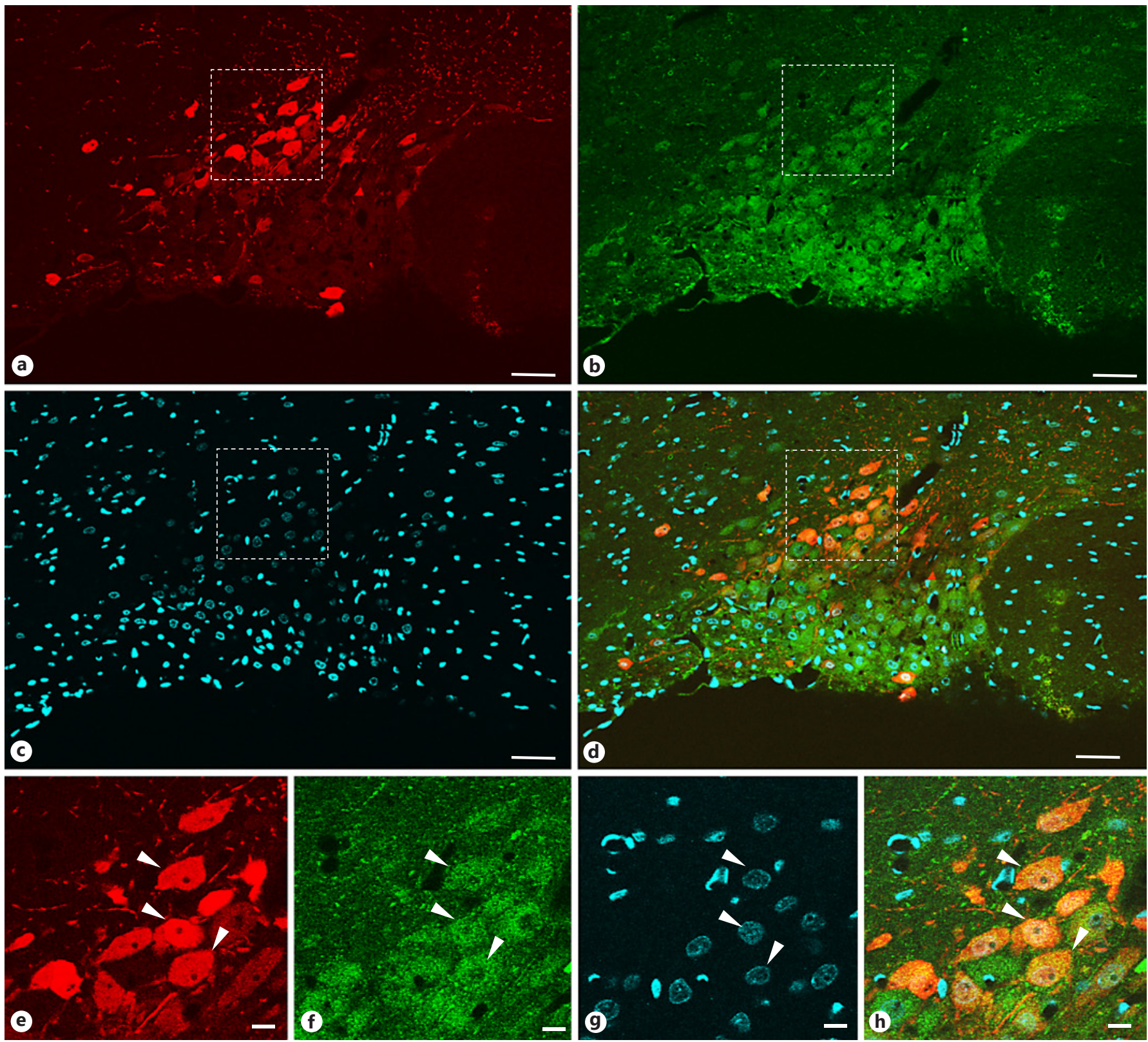

Fig. 2. Co-localization of oxytocin and Kir6.2 in the SON. The fluorescence image of oxytocin (a), Kir 6.2 (b), nuclear staining of DAPI (c), and merged images $(\mathbf{d})$. e-h Enlarged images of dotted squares in a-d, respectively. Scale bars $=50 \mu \mathrm{m}(\mathbf{a}-\mathbf{d})$ and $10 \mu \mathrm{m}(\mathbf{e}-\mathbf{h})$.

[17], and schizophrenia [18] in humans. In addition, obesity prevention is expected in future through the use of oxytocin treatment.

From a clinical point of view, nasal treatment of oxytocin is attracting attention [125], as it is noninvasive [126]. However, it remains unclear how oxytocin effects the CNS [127]. Whether intranasal oxytocin acts on the

Anorexigenic Oxytocin and Clinical Implications
CNS through peripheral oxytocin receptors (such as through vagal afferents) or directly on CNS oxytocin receptors is controversial. We have recently reported that nasal administration of oxytocin decreases food intake without affecting locomotor activity and peripheral glucose metabolism in mice [24]. Interestingly, IP injection of oxytocin increased c-fos expression in various brain

Neuroendocrinology 2018;107:91-104 DOI: $10.1159 / 000489263$ 
regions including the PVN, ARC, AP, NTS and DMNV, whereas the nasal administration of oxytocin increased c-fos in limited brain regions including the PVN, AP, and DMNV [24]. These results indicate the different anorexigenic pathways of oxytocin between the nasal and IP injection, and both treatments (IP and nasal) could stimulate the CNS.

Concerning the IP and subcutaneous injection of oxytocin, its anorexigenic effect may act through the vagal afferent pathway [128]. It is known that oxytocin receptors are distributed in the gastrointestinal tract and nodose ganglion [129], and anorexigenic effects and c-fos expression in the NTS induced by the IP oxytocin injection are partly blunted by vagotomy [128]. On the other hand, there is no c-fos expression in the NTS after nasal oxytocin treatment [24]. However, it is possible that nasal treatment of oxytocin acts through a peripheral mechanism. Further study is required to clarify this mechanism.

Our report, as well as others, has confirmed the subchronic effects of peripheral oxytocin treatment in the animal obesity model $[23,29,34,37,39,130,131]$. Although the pharmacokinetics of peripherally injected oxytocin remains unclear, oxytocin is reported to cross the blood-brain barrier [132] by $0.002 \%$ [133]. A recent study using rhesus monkeys also demonstrated that the d5-deuterated oxytocin is delivered into cerebrospinal fluid after intranasal and intravenous injection [134].

When oxytocin infusions were applied from a subcutaneously implanted osmotic mini-pump $(1,600 \mu \mathrm{g} / \mathrm{kg} /$ day) for 10-14 days to HFD-induced obese mice, BW dramatically decreased ( $10 \%$ of initial BW) within 2 days, and food intake was decreased for 7 days after oxytocin treatment was initiated in both male and female mice [23, 39]. The oxytocin effect on BW was dose dependent [39], and reduced BW was maintained throughout the oxytocin treatment period. We found that mice showed increased energy expenditure with decreased respiratory quotient (RQ) during the light phase of the treatment period [23]. The RQ decrease by oxytocin treatment was also confirmed in rats, monkeys, and humans $[25,32,34$, $35,135]$. This reduction of BW by oxytocin may also be mediated by the induction of diet-induced thermogenesis $[31,47]$. Other factors related to the metabolic disorder were also found to be affected by the oxytocin treatment. The lipid droplets concentrated in the hepatocyte induced by HFD intake were decreased, and the size of adipocytes in the mesenteric fat (common abdominal fat) was also decreased after oxytocin treatment [23]. In HFDinduced obese male and female mice (body fat mass: $36 \%), 10$ days of oxytocin treatment decreased abdominal and subcutaneous fat up to $15-20 \%$ without reducing muscle mass [39]. Similar effects of oxytocin on fat mass are found in other studies using HFD-induced obese mice/rats $[25,29,31,32]$ and genetically obese models such as db/db [131] and ob/ob mice [37]. This suggests that the cause of decreased BW induced by oxytocin treatment depends not only on the decreased food intake, but also on the stimulation of lipolysis. Oxytocin receptors are expressed in various tissues, including adipose tissue $[38,92]$, and previous articles reported that oxytocin increases lipolysis and fatty acid $\beta$-oxidation by acting directly on adipose tissue in rats $[29,136]$. Blevins et al. [34] demonstrated that, in addition to rodents, subcutaneous oxytocin treatment reduces BW in diet-induced obesity primates (rhesus monkey) with decreased food intake, increased energy expenditure, and lipolysis. These reports emphasize the importance of oxytocin in affecting lipid metabolism in adipose tissue, as well as in food intake regulation.

Furthermore, chronic treatment of oxytocin is reported to also be effective in reducing BW in a leptin-resistant obese model such as $\mathrm{db} / \mathrm{db}$ mice $[128,131]$, ob/ob mice [37], Koletsky rats [28], and Zucker fatty rats [137], indicating that the oxytocin effect is independent from the leptin effect. Because human obesity is based on leptin resistance, the fact that oxytocin is effective even in leptinresistant animal models indicates a strong advantage of oxytocin as an anti-obesity agent.

A recent article reported that circulating oxytocin levels are decreased in obesity and type 2 diabetic patients [138, 139], HFD-induced obese mice [25], and Zucker fatty rats [38]. This decrease in plasma oxytocin levels may be a result of severe obesity since significant plasma oxytocin degradation was not confirmed in the studies using obese models fed HFD for 8-16 weeks [28, 39]. Moreover, the activity of oxytocinase (the main enzyme involved in oxytocin degradation) was elevated in the liver and adipose tissue in the obese Zucker fatty rats [38], whereas oxytocin receptor mRNA and/or protein levels were upregulated in the adipose tissue in the Zucker fatty rats [28] and hypothalamus in the HFD-induced obese mice $[25,140]$.

We reported a negative correlation between oxytocin's effect on BW and initial BW in HFD-induced obese mice. We found that the mice with higher initial BW showed more effective reduction in BW by oxytocin treatment in both males and females [39]. Since most anorexigenic oxytocin effects have been studied in males, the details of gender difference remain unclear. However, our recent study showed that there were no gender differences in the effect of oxytocin on BW reduction in mice [39]. This is 
Fig. 3. The potential of oxytocin as an antiobesity drug. Obesity increases plasma leptin levels and promotes leptin resistance. On the other hand, obesity decreases plasma oxytocin levels and increases oxytocin receptor expression in adipose tissue and the central nervous system. Thus, exogenous oxytocin decreases fat mass and food intake in severely obese animals/humans. Since oxytocin decreases fat mass and food intake in leptin-resistant animal models, it may improve leptin resistance. In addition, oxytocin protects insulin-secreting pancreatic $\beta$-cells in obese conditions, promotes insulin secretion, and improves fatty liver.

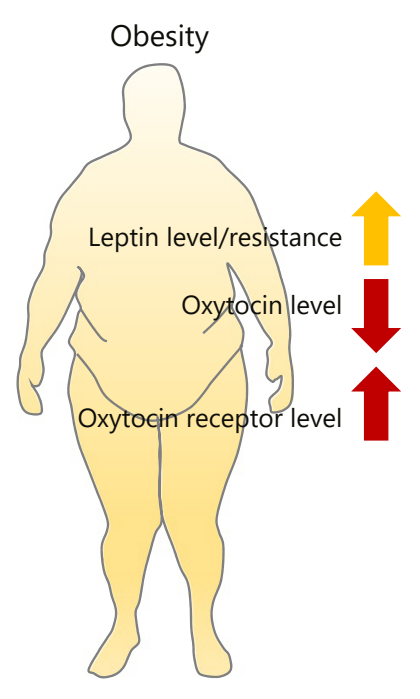

Exogenous oxytocin in obesity

- Large effect on fat mass and food intake in severe obesity

- Improves leptin resistance followed by decreased fat mass and food intake in leptin-resistant model

Improves glucose tolerance, protects $\beta$-cells, improves insulin secretion

Improves fatty liver consistent with a report by Benelli et al. [141], which showed that there is no gender difference in oxytocininduced inhibition of feeding in rats. This BW degradation was found to be the consequence of reduced energy intake and fat mass $[23,39]$. On the other hand, the effect of oxytocin on BW degradation was smaller in lean mice or rats fed a normal chow diet $[32,37,39]$. This phenomenon was also observed in Zucker lean and fatty rats [137] and Koletsky rats [28]. This is consistent with studies in humans showing oxytocin's inhibitory effect on food intake being stronger in obese men than normal-weight men [36], and the degree of oxytocin's BW degradation being greater in severe obesity $(\mathrm{BMI}>35)$ than mild obesity $(\mathrm{BMI}<30)$ [142].

As described previously, the underlying mechanism of oxytocin's anti-obesity effects being more potent in severe obesity in rodents and humans (fat mass degradation and food intake inhibition) may be due to the increment of oxytocin receptor expression in the brain and adipose tissue. In other words, severe obesity may increase the sensitivity to oxytocin in the brain and adipose tissue.

Severe obesity generally promotes insulin and leptin resistance, followed by an increase in plasma leptin and insulin levels. Thus, promoted insulin and leptin resistance exacerbates diabetes and obesity. In contrast, in obese conditions, plasma oxytocin levels are decreased, and oxytocin receptors are increased without oxytocin resistance. This is a significant advantage of oxytocin as an anti-obesity treatment, since it may decrease fat mass and therefore induce reduction of plasma leptin levels, which ultimately leads to improvement of leptin resistance. In addition, oxytocin is known to protect insulin-secreting $\beta$-cells from chronic high-glucose conditions in mice and humans [140,143], promote insulin secretion [24], and improve glucose tolerance in mice [23, 24, 128] (Fig. 3).

One important consideration is that peripheral administration of oxytocin may result in the release of endogenous oxytocin within the CNS, [26] through the vagal afferent and ascending projection from the NTS [26, $28,128]$ in rodents. Since nasal treatment of oxytocin failed to show any effect on Prader-Willi syndrome patients, whose PVN oxytocin neurons are almost completely lost [144], the anorexigenic effect of nasal oxytocin treatment may also come from the release of endogenous oxytocin within the hypothalamus. These reports indicate that the induction of endogenous oxytocin secretion triggered by exogenous oxytocin administration is the main mechanism for its anti-obesity effect. However, neither intranasal nor intravenous injection of oxytocin led to increased endogenous oxytocin in the CSF of monkeys [134]. Further studies of the anorexigenic effect of oxytocin and exogenous oxytocin-induced endogenous oxytocin are needed in the future. Because the effect of oxytocin on the CNS has a substantial contribution to food intake and $\mathrm{BW}$ regulation, the discovery of an agent that may induce central oxytocin release is highly anticipated.

Furthermore, all studies using intranasal oxytocin as an experimental intervention presented in this review have limitations and controversies. Further research on its clinical application is required. 


\section{Conclusion}

Considering the global increase in the number of obese and metabolic syndrome patients, oxytocin treatment has various advantages and is a promising treatment for obesity and related metabolic disorders (Fig. 3). The advantage of oxytocin treatment is further enhanced by the following facts: (1) there is no oxytocin resistance in obese patients; (2) there are no severe adverse effects reported thus far; and (3) oxytocin has already been used in the clinical setting for decades for the promotion of delivery and milk ejection after birth.

Recently, Higashida et al. [145] reported that oxytocin is transmitted into blood in the intestinal tract via the mediation of receptors for glycation end products in adult mice. Oral oxytocin supplementation could be another potential anti-obesity treatment.

Taking these facts into consideration, oxytocin may potentially be a safe and effective anti-obesity drug.

\section{Disclosure Statement}

The authors declare that there is no conflict of interest.

\section{Funding Sources}

This work was supported by a Grant-Aid for Scientific Research ${ }^{\odot}$ (15K09395) and The TANITA Healthy Weight Community Trust to Y.M, Grant-Aid for Scientific Research ${ }^{\circledR}$ (26461366) to K.S.

\section{References}

1 Dale HH: On some physiological actions of ergot. J Physiol 1906;34:163-206.

2 Du Vigneaud V, Ressler C, Trippett S: The sequence of amino acids in oxytocin, with a proposal for the structure of oxytocin. J Biol Chem 1953;205:949-957.

3 Donaldson ZR, Young LJ: Oxytocin, vasopressin, and the neurogenetics of sociality. Science 2008;322:900-904.

4 Bargman W, Scharrer E: The site of origin of the hormones of the pituitary. Am Sci 1951; 39:255-259.

5 Ludwig M, Sabatier N, Bull PM, Landgraf R, Dayanithi G, Leng G: Intracellular calcium stores regulate activity-dependent neuropeptide release from dendrites. Nature 2002;418: 85-89.

6 Maejima Y, Sakuma K, Santoso P, Gantulga D, Katsurada K, Ueta Y, Hiraoka Y, Nishimori K, Tanaka S, Shimomura K, Yada T: Oxytocinergic circuit from paraventricular and supraoptic nuclei to arcuate POMC neurons in hypothalamus. FEBS Lett 2014;588:4404-4412.

7 Kosfeld M, Heinrichs M, Zak PJ, Fischbacher U, Fehr E: Oxytocin increases trust in humans. Nature 2005;435:673-676.

8 Veening JG, Olivier B: Intranasal administration of oxytocin: behavioral and clinical effects, a review. Neurosci Biobehav Rev 2013; 37:1445-1465.

9 Naber F, van Ijzendoorn MH, Deschamps P, van Engeland H, Bakermans-Kranenburg MJ: Intranasal oxytocin increases fathers' observed responsiveness during play with their children: a double-blind within-subject experiment. Psychoneuroendocrinology 2010; 35:1583-1586.

10 Jin D, Liu HX, Hirai H, Torashima T, Nagai T, Lopatina O, Shnayder NA, Yamada K,
Noda M, Seike T, Fujita K, Takasawa S, Yokoyama S, Koizumi K, Shiraishi Y, Tanaka S, Hashii M, Yoshihara T, Higashida K, Islam MS, Yamada N, Hayashi K, Noguchi N, Kato I, Okamoto H, Matsushima A, Salmina A, Munesue T, Shimizu N, Mochida S, Asano M, Higashida H: CD38 is critical for social behaviour by regulating oxytocin secretion. Nature 2007;446:41-45.

11 Stoop R, Hegoburu C, van den Burg E: New opportunities in vasopressin and oxytocin research: a perspective from the amygdala. Annu Rev Neurosci 2015;38:369-388.

12 Johnson ZV, Walum H, Jamal YA, Xiao Y, Keebaugh AC, Inoue $\mathrm{K}$, Young LJ: Central oxytocin receptors mediate mating-induced partner preferences and enhance correlated activation across forebrain nuclei in male prairie voles. Horm Behav 2016; 79:8-17.

13 Numan M, Young LJ: Neural mechanisms of mother-infant bonding and pair bonding: Similarities, differences, and broader implications. Horm Behav 2016;77:98-112.

14 Domes G, Heinrichs M, Michel A, Berger C, Herpertz SC: Oxytocin improves "mindreading" in humans. Biol Psychiatry 2007;61: 731-733.

15 Andari E, Hurlemann R, Young LJ: A precision medicine approach to oxytocin trials. Curr Top Behav Neurosci DOI: 10.1007/ 7854_2017_29.

16 Burkett JP, Andari E, Johnson ZV, Curry DC, de Waal FB, Young LJ: Oxytocin-dependent consolation behavior in rodents. Science 2016;351:375-378.

17 Aoki Y, Yahata N, Watanabe T, Takano Y, Kawakubo Y, Kuwabara H, Iwashiro N, Natsubori T, Inoue H, Suga M, Takao H, Sasaki
H, Gonoi W, Kunimatsu A, Kasai K, Yamasue $\mathrm{H}$ : Oxytocin improves behavioural and neural deficits in inferring others' social emotions in autism. Brain 2014;137:3073-3086.

18 Bradley ER, Woolley JD: Oxytocin effects in schizophrenia: reconciling mixed findings and moving forward. Neurosci Biobehav Rev 2017;80:36-56.

19 Wang T, Shi C, Li X, Zhang P, Liu B, Wang H, Wang Y, Yang Y, Wu Y, Li H, Xu ZD: Injection of oxytocin into paraventricular nucleus reverses depressive-like behaviors in the postpartum depression rat model. Behav Brain Res 2018;336:236-243.

20 Feldman R, Monakhov M, Pratt M, Ebstein RP: Oxytocin pathway genes: evolutionary ancient system impacting on human affiliation, sociality, and psychopathology. Biol Psychiatry 2016;79:174-184.

21 Altirriba J, Poher AL, Rohner-Jeanrenaud F: Chronic oxytocin administration as a treatment against impaired leptin signaling or leptin resistance in Obesity. Front Endocrinol (Lausanne) 2015;6:119.

22 Arletti R, Benelli A, Bertolini A: Influence of oxytocin on feeding behavior in the rat. Peptides 1989;10:89-93.

23 Maejima Y, Iwasaki Y, Yamahara Y, Kodaira M, Sedbazar U, Yada T: Peripheral oxytocin treatment ameliorates obesity by reducing food intake and visceral fat mass. Aging (Albany NY) 2011;3:1169-1177.

24 Maejima Y, Rita RS, Santoso P, Aoyama M, Hiraoka $Y$, Nishimori K, Gantulga D, Shimomura $\mathrm{K}$, Yada T: Nasal oxytocin administration reduces food intake without affecting locomotor activity and glycemia with c-Fos induction in limited brain areas. Neuroendocrinology 2015; 101:35-44. 
25 Zhang G, Bai H, Zhang H, Dean C, Wu Q, Li J, Guariglia S, Meng Q, Cai D: Neuropeptide exocytosis involving synaptotagmin-4 and oxytocin in hypothalamic programming of body weight and energy balance. Neuron 2011;69:523-535.

26 Zhang G, Cai D: Circadian intervention of obesity development via resting-stage feeding manipulation or oxytocin treatment. Am J Physiol Endocrinol Metab 2011;301:E1004E1012.

27 Arletti R, Benelli A, Bertolini A: Oxytocin inhibits food and fluid intake in rats. Physiol Behav 1990;48:825-830.

28 Morton GJ, Thatcher BS, Reidelberger RD, Ogimoto K, Wolden-Hanson T, Baskin DG, Schwartz MW, Blevins JE: Peripheral oxytocin suppresses food intake and causes weight loss in diet-induced obese rats. Am J Physiol Endocrinol Metab 2012;302:E134-E144.

29 Deblon N, Veyrat-Durebex C, Bourgoin L, Caillon A, Bussier AL, Petrosino S, Piscitelli F, Legros JJ, Geenen V, Foti M, Wahli W, Di Marzo V, Rohner-Jeanrenaud F: Mechanisms of the anti-obesity effects of oxytocin in dietinduced obese rats. PLoS One 2011;6:e25565.

30 Olson BR, Drutarosky MD, Chow MS, Hruby VJ, Stricker EM, Verbalis JG: Oxytocin and an oxytocin agonist administered centrally decrease food intake in rats. Peptides 1991;12: 113-118.

31 Roberts ZS, Wolden-Hanson T, Matsen ME, Ryu V, Vaughan CH, Graham JL, Havel PJ, Chukri DW, Schwartz MW, Morton GJ, Blevins JE: Chronic hindbrain administration of oxytocin is sufficient to elicit weight loss in diet-induced obese rats. Am J Physiol Regul Integr Comp Physiol 2017;313:R357-R371.

32 Blevins JE, Thompson BW, Anekonda VT, Ho JM, Graham JL, Roberts ZS, Hwang BH, Ogimoto K, Wolden-Hanson T, Nelson J, Kaiyala KJ, Havel PJ, Bales KL, Morton GJ, Schwartz MW, Baskin DG: Chronic CNS oxytocin signaling preferentially induces fat loss in high-fat diet-fed rats by enhancing satiety responses and increasing lipid utilization. Am J Physiol Regul Integr Comp Physiol 2016; 310:R640-R658.

33 Ong ZY, Alhadeff AL, Grill HJ: Medial nucleus tractus solitarius oxytocin receptor signaling and food intake control: the role of gastrointestinal satiation signal processing. Am J Physiol Regul Integr Comp Physiol 2015; 308:R800-R806.

34 Blevins JE, Graham JL, Morton GJ, Bales KL, Schwartz MW, Baskin DG, Havel PJ: Chronic oxytocin administration inhibits food intake, increases energy expenditure, and produces weight loss in fructose-fed obese rhesus monkeys. Am J Physiol Regul Integr Comp Physiol 2015;308:R431-R438.

35 Lawson EA, Marengi DA, DeSanti RL, Holmes TM, Schoenfeld DA, Tolley CJ: Oxytocin reduces caloric intake in men. Obesity (Silver Spring) 2015;23:950-956.
36 Thienel M, Fritsche A, Heinrichs M, Peter A, Ewers M, Lehnert H, Born J, Hallschmid M: Oxytocin's inhibitory effect on food intake is stronger in obese than normal-weight men. Int J Obes (Lond) 2016;40:1707-1714.

37 Altirriba J, Poher AL, Caillon A, Arsenijevic D, Veyrat-Durebex C, Lyautey J, Dulloo A, Rohner-Jeanrenaud F: Divergent effects of oxytocin treatment of obese diabetic mice on adiposity and diabetes. Endocrinology 2014; 155:4189-4201

38 Gajdosechova L, Krskova K, Segarra AB, Spolcova A, Suski M, Olszanecki R, Zorad S: Hypooxytocinaemia in obese Zucker rats relates to oxytocin degradation in liver and adipose tissue. J Endocrinol 2014;220:333343.

39 Maejima Y, Aoyama M, Sakamoto K, Jojima T, Aso Y, Takasu K, Takenosihita S, Shimomura K: Impact of sex, fat distribution and initial body weight on oxytocin's body weight regulation. Sci Rep 2017;7:8599.

40 Yi KJ, So KH, Hata Y, Suzuki Y, Kato D, Watanabe K, Aso H, Kasahara Y, Nishimori K, Chen C, Katoh K, Roh SG: The regulation of oxytocin receptor gene expression during adipogenesis. J Neuroendocrinol 2015;27:335-342.

41 Johnstone LE, Fong TM, Leng G: Neuronal activation in the hypothalamus and brainstem during feeding in rats. Cell Metab 2006; 4:313-321.

42 Hume C, Sabatier N, Menzies J: High-sugar, but not high-fat, food activates supraoptic nucleus neurons in the male rat. Endocrinology 2017;158:2200-2211.

43 Kublaoui BM, Gemelli T, Tolson KP, Wang Y, Zinn AR: Oxytocin deficiency mediates hyperphagic obesity of Sim1 haploinsufficient mice. Mol Endocrinol 2008;22:1723-1734.

44 Tung YC, Ma M, Piper S, Coll A, O’Rahilly S, Yeo GS: Novel leptin-regulated genes revealed by transcriptional profiling of the hypothalamic paraventricular nucleus. J Neurosci 2008;28:12419-12426.

45 Wu Z, Xu Y, Zhu Y, Sutton AK, Zhao R, Lowell BB, Olson DP, Tong Q: An obligate role of oxytocin neurons in diet induced energy expenditure. PLoS One 2012;7:e45167.

46 Baskin DG, Kim F, Gelling RW, Russell BJ, Schwartz MW, Morton GJ, Simhan HN, Moralejo DH, Blevins JE: A new oxytocin-saporin cytotoxin for lesioning oxytocin-receptive neurons in the rat hindbrain. Endocrinology 2010;151:4207-4213.

47 Ong ZY, Bongiorno DM, Hernando MA, Grill HJ: Effects of endogenous oxytocin receptor signaling in nucleus tractus solitarius on satiation-mediated feeding and thermogenic control in male rats. Endocrinology 2017;158:2826-2836.

48 Fenselau H, Campbell JN, Verstegen AM, Madara JC, Xu J, Shah BP, Resch JM, Yang Z, Mandelblat-Cerf Y, Livneh Y, Lowell BB: A rapidly acting glutamatergic $\mathrm{ARC} \rightarrow \mathrm{PVH}$ satiety circuit postsynaptically regulated by $\alpha$ MSH. Nat Neurosci 2017;20:42-51.
49 Maejima Y, Takahashi S, Takasu K, Takenoshita S, Ueta Y, Shimomura K: Orexin action on oxytocin neurons in the paraventricular nucleus of the hypothalamus. Neuroreport 2017;28:360-366.

50 Takayanagi Y, Kasahara Y, Onaka T, Takahashi N, Kawada T, Nishimori K: Oxytocin receptor-deficient mice developed late-onset obesity. Neuroreport 2008; 19:951-955.

51 Schwartz MW, Woods SC, Porte D Jr, Seeley RJ, Baskin DG: Central nervous system control of food intake. Nature 2000;404:661-671.

52 Oh-I S, Shimizu H, Satoh T, Okada S, Adachi $\mathrm{S}$, Inoue $\mathrm{K}$, Eguchi $\mathrm{H}$, Yamamoto $\mathrm{M}$, Imaki $\mathrm{T}$, Hashimoto K, Tsuchiya T, Monden T, Horiguchi K, Yamada M, Mori M: Identification of nesfatin- 1 as a satiety molecule in the hypothalamus. Nature 2006;443:709-712.

53 Maejima Y, Sedbazar U, Suyama S, Kohno D, Onaka T, Takano E, Yoshida N, Koike M, Uchiyama Y, Fujiwara K, Yashiro T, Horvath TL, Dietrich MO, Tanaka S, Dezaki K, Oh-I S, Hashimoto K, Shimizu H, Nakata M, Mori M, Yada T: Nesfatin-1-regulated oxytocinergic signaling in the paraventricular nucleus causes anorexia through a leptin-independent melanocortin pathway. Cell Metab 2009; 10:355-365.

54 Toriya M, Maekawa F, Maejima Y, Onaka T, Fujiwara K, Nakagawa T, Nakata M, Yada T: Long-term infusion of brain-derived neurotrophic factor reduces food intake and body weight via a corticotrophin-releasing hormone pathway in the paraventricular nucleus of the hypothalamus. J Neuroendocrinol 2010;22:987-995.

55 Bouret SG, Draper SJ, Simerly RB: Trophic action of leptin on hypothalamic neurons that regulate feeding. Science 2004;304:108-110.

56 Williams KW, Elmquist JK: From neuroanatomy to behavior: central integration of peripheral signals regulating feeding behavior. Nat Neurosci 2012;15:1350-1355.

57 da Silva AA, do Carmo JM, Wang Z, Hall JE: The brain melanocortin system, sympathetic control, and obesity hypertension. Physiology (Bethesda) 2014;29:196-202.

58 Mountjoy KG, Mortrud MT, Low MJ, Simerly RB, Cone RD: Localization of the melanocortin-4 receptor (MC4-R) in neuroendocrine and autonomic control circuits in the brain. Mol Endocrinol 1994;8:1298-1308.

59 Butler AA, Marks DL, Fan W, Kuhn CM, Bartolome M, Cone RD: Melanocortin-4 receptor is required for acute homeostatic responses to increased dietary fat. Nat Neurosci 2001; 4:605-611.

60 O’Rahilly S, Yeo GS, Farooqi IS: Melanocortin receptors weigh in. Nat Med 2004;10:351352.

61 Hanson ES, Dallman MF: Neuropeptide Y (NPY) may integrate responses of hypothalamic feeding systems and the hypothalamopituitary-adrenal axis. J Neuroendocrinol 1995;7:273-279. 
62 Aponte Y, Atasoy D, Sternson SM: AGRP neurons are sufficient to orchestrate feeding behavior rapidly and without training. Nat Neurosci 2011;14:351-355.

63 Horvath TL: The hardship of obesity: a softwired hypothalamus. Nat Neurosci 2005;8: 561-565.

64 Langlet F, Levin BE, Luquet S, Mazzone M, Messina A, Dunn-Meynell AA, Balland E, Lacombe A, Mazur D, Carmeliet P, Bouret SG, Prevot V, Dehouck B: Tanycytic VEGF-A boosts blood-hypothalamus barrier plasticity and access of metabolic signals to the arcuate nucleus in response to fasting. Cell Metab 2013;17:607-617.

65 Caquineau C, Leng G, Guan XM, Jiang M, Van der Ploeg L, Douglas AJ: Effects of alphamelanocyte-stimulating hormone on magnocellular oxytocin neurones and their activation at intromission in male rats. J Neuroendocrinol 2006;18:685-691.

66 Siljee JE, Unmehopa UA, Kalsbeek A, Swaab DF, Fliers E, Alkemade A: Melanocortin 4 receptor distribution in the human hypothalamus. Eur J Endocrinol 2013;168:361369.

67 Liu H, Kishi T, Roseberry AG, Cai X, Lee CE, Montez JM, Friedman JM, Elmquist JK: Transgenic mice expressing green fluorescent protein under the control of the melanocortin-4 receptor promoter. J Neurosci 2003;23: 7143-7154.

68 Wirth MM, Olszewski PK, Yu C, Levine AS, Giraudo SQ: Paraventricular hypothalamic alpha-melanocyte-stimulating hormone and MTII reduce feeding without causing aversive effects. Peptides 2001;22:129-134.

69 Olszewski PK, Wirth MM, Shaw TJ, Grace MK, Billington CJ, Giraudo SQ, Levine AS: Role of alpha-MSH in the regulation of consummatory behavior: immunohistochemical evidence. Am J Physiol Regul Integr Comp Physiol 2001;281:R673-R680.

70 Singru PS, Wittmann G, Farkas E, Zséli G, Fekete C, Lechan RM: Refeeding-activated glutamatergic neurons in the hypothalamic paraventricular nucleus (PVN) mediate effects of melanocortin signaling in the nucleus tractus solitarius (NTS). Endocrinology 2012; 153:3804-3814.

71 Yosten GL, Samson WK: The anorexigenic and hypertensive effects of nesfatin-1 are reversed by pretreatment with an oxytocin receptor antagonist. Am J Physiol Regul Integr Comp Physiol 2010;298:R1642-R1647.

72 Atasoy D, Betley JN, Su HH, Sternson SM: Deconstruction of a neural circuit for hunger. Nature 2012;488:172-177.

73 Wolak ML, DeJoseph MR, Cator AD, Mokashi AS, Brownfield MS, Urban JH: Comparative distribution of neuropeptide Y Y1 and $\mathrm{Y} 5$ receptors in the rat brain by using immunohistochemistry. J Comp Neurol 2003; 464:285-311.
74 Schwartz GJ: Integrative capacity of the caudal brainstem in the control of food intake. Philos Trans R Soc Lond B Biol Sci 2006;361: 1275-1280.

75 Peters JH, Simasko SM, Ritter RC: Modulation of vagal afferent excitation and reduction of food intake by leptin and cholecystokinin. Physiol Behav 2006;89:477-485.

76 Ronveaux CC, Tomé D, Raybould HE: Glucagon-like peptide 1 interacts with ghrelin and leptin to regulate glucose metabolism and food intake through vagal afferent neuron signaling. J Nutr 2015;145:672-680.

77 Iwasaki Y, Shimomura K, Kohno D, Dezaki K, Ayush EA, Nakabayashi H, Kubota N, Kadowaki T, Kakei M, Nakata M, Yada T: Insulin activates vagal afferent neurons including those innervating pancreas via insulin cascade and $\mathrm{Ca}^{2+}$ influx: its dysfunction in IRS2KO mice with hyperphagic obesity. PLoS One 2013;8:e67198.

78 Affleck VS, Coote JH, Pyner S: The projection and synaptic organisation of NTS afferent connections with presympathetic neurons, GABA and nNOS neurons in the paraventricular nucleus of the hypothalamus. Neuroscience 2012;219:48-61.

79 Katsurada K, Maejima Y, Nakata M, Kodaira M, Suyama S, Iwasaki Y, Kario K, Yada T: Endogenous GLP-1 acts on paraventricular nucleus to suppress feeding: projection from nucleus tractus solitarius and activation of corticotropin-releasing hormone, nesfatin-1 and oxytocin neurons. Biochem Biophys Res Commun 2014;451:276-281.

80 Motojima Y, Kawasaki M, Matsuura T, Saito $\mathrm{R}$, Yoshimura $\mathrm{M}$, Hashimoto $\mathrm{H}$, Ueno $\mathrm{H}$, Maruyama T, Suzuki H, Ohnishi H, Sakai A, Ueta Y: Effects of peripherally administered cholecystokinin-8 and secretin on feeding/ drinking and oxytocin-mRFP1 fluorescence in transgenic rats. Neurosci Res 2016;109:6369.

81 Katoh A, Shoguchi K, Matsuoka H, Yoshimura M, Ohkubo JI, Matsuura T, Maruyama T, Ishikura T, Aritomi T, Fujihara $\mathrm{H}$, Hashimoto H, Suzuki H, Murphy D, Ueta Y: Fluorescent visualisation of the hypothalamic oxytocin neurones activated by cholecystokinin-8 in rats expressing c-fos-enhanced green fluorescent protein and oxytocin-monomeric red fluorescent protein 1 fusion transgenes. J Neuroendocrinol 2014;26:341347.

82 D’Agostino G, Lyons DJ, Cristiano C, Burke LK, Madara JC, Campbell JN, Garcia AP, Land BB, Lowell BB, Dileone RJ, Heisler LK: Appetite controlled by a cholecystokinin nucleus of the solitary tract to hypothalamus neurocircuit. Elife 2016;5:pii: e12225.

83 Zhan C, Zhou J, Feng Q, Zhang JE, Lin S, Bao J, Wu P, Luo M: Acute and long-term suppression of feeding behavior by POMC neurons in the brainstem and hypothalamus, respectively. J Neurosci 2013;33:36243632.
84 Fan W, Ellacott KL, Halatchev IG, Takahashi K, Yu P, Cone RD: Cholecystokinin-mediated suppression of feeding involves the brainstem melanocortin system. Nat Neurosci 2004;7: 335-336.

85 Appleyard SM, Bailey TW, Doyle MW, Jin YH, Smart JL, Low MJ, Andresen MC: Proopiomelanocortin neurons in nucleus tractus solitarius are activated by visceral afferents: regulation by cholecystokinin and opioids. J Neurosci 2005;25:3578-3585.

86 Sawchenko PE, Swanson LW: Immunohistochemical identification of neurons in the paraventricular nucleus of the hypothalamus that project to the medulla or to the spinal cord in the rat. J Comp Neurol 1982;205:260272.

87 Blevins JE, Schwartz MW, Baskin DG: Evidence that paraventricular nucleus oxytocin neurons link hypothalamic leptin action to caudal brain stem nuclei controlling meal size. Am J Physiol Regul Integr Comp Physiol 2004;287:R87-R96.

88 Ho JM, Anekonda VT, Thompson BW, Zhu M, Curry RW, Hwang BH, Morton GJ, Schwartz MW, Baskin DG, Appleyard SM, Blevins JE: Hindbrain oxytocin receptors contribute to the effects of circulating oxytocin on food intake in male rats. Endocrinology 2014;155:2845-2857.

89 Llewellyn-Smith IJ, Kellett DO, Jordan D, Browning KN, Travagli RA: Oxytocin-immunoreactive innervation of identified neurons in the rat dorsal vagal complex. Neurogastroenterol Motil 2012;24:e136-e146.

90 Browning KN, Travagli RA: Plasticity of vagal brainstem circuits in the control of gastrointestinal function. Auton Neurosci 2011;161: 6-13.

91 Rogers RC, Hermann GE: Oxytocin, oxytocin antagonist, TRH, and hypothalamic paraventricular nucleus stimulation effects on gastric motility. Peptides 1987;8:505-513.

92 Gimpl G, Fahrenholz F: The oxytocin receptor system: structure, function, and regulation. Physiol Rev 2001;81:629-683.

93 Csiffáry A, Ruttner Z, Tóth Z, Palkovits M: Oxytocin nerve fibers innervate beta-endorphin neurons in the arcuate nucleus of the rat hypothalamus. Neuroendocrinology 1992;56: 429-435.

94 Krashes MJ, Shah BP, Madara JC, Olson DP, Strochlic DE, Garfield AS, Vong L, Pei H, Watabe-Uchida M, Uchida N, Liberles SD, Lowell BB: An excitatory paraventricular nucleus to AgRP neuron circuit that drives hunger. Nature 2014;507:238-242.

95 Maejima Y, Kumamoto K, Takenoshita S, Shimomura K: Projections from a single NUCB2/nesfatin-1 neuron in the paraventricular nucleus to different brain regions involved in feeding. Brain Struct Funct 2016; 221:4723-4731. 
96 Foo KS, Brismar H, Broberger C: Distribution and neuropeptide coexistence of nucleobindin-2 mRNA/nesfatin-like immunoreactivity in the rat CNS. Neuroscience 2008; 156:563-579.

97 Adamantidis AR, Tsai HC, Boutrel B, Zhang F, Stuber GD, Budygin EA, Touriño C, Bonci A, Deisseroth K, de Lecea L: Optogenetic interrogation of dopaminergic modulation of the multiple phases of reward-seeking behavior. J Neurosci 2011;31:10829-10835.

98 Watabe-Uchida M, Zhu L, Ogawa SK, Vamanrao A, Uchida N: Whole-brain mapping of direct inputs to midbrain dopamine neurons. Neuron 2012;74:858-873.

99 van Zessen R, Phillips JL, Budygin EA, Stuber GD: Activation of VTA GABA neurons disrupts reward consumption. Neuron 2012;73:1184-1194.

100 Volkow ND, Morales M: The brain on drugs: from reward to addiction. Cell 2015; 162:712-725.

101 Johnson PM, Kenny PJ: Dopamine D2 receptors in addiction-like reward dysfunction and compulsive eating in obese rats. Nat Neurosci 2010;13:635-641.

102 Valdivia S, Patrone A, Reynaldo M, Perello M: Acute high fat diet consumption activates the mesolimbic circuit and requires orexin signaling in a mouse model. PLoS One 2014;9:e87478.

103 Kenny PJ: Reward mechanisms in obesity: new insights and future directions. Neuron 2011;69:664-679.

104 Morales-Rivera A, Hernández-Burgos MM, Martínez-Rivera A, Pérez-Colón J, Rivera R, Montalvo J, Rodríguez-Borrero E, Maldonado-Vlaar CS: Anxiolytic effects of oxytocin in cue-induced cocaine seeking behavior in rats. Psychopharmacology (Berl) 2014;231: 4145-4155.

105 Mullis K, Kay K, Williams DL: Oxytocin action in the ventral tegmental area affects sucrose intake. Brain Res 2013;1513:85-91.

106 Olszewski PK, Klockars A, Olszewska AM, Fredriksson R, Schiöth HB, Levine AS: Molecular, immunohistochemical, and pharmacological evidence of oxytocin's role as inhibitor of carbohydrate but not fat intake. Endocrinology 2010;151:4736-4744.

107 Amico JA, Vollmer RR, Cai HM, Miedlar JA, Rinaman L: Enhanced initial and sustained intake of sucrose solution in mice with an oxytocin gene deletion. Am J Physiol Regul Integr Comp Physiol 2005;289:R1798R1806.

108 Ott V, Finlayson G, Lehnert H, Heitmann B, Heinrichs M, Born J, Hallschmid M: Oxytocin reduces reward-driven food intake in humans. Diabetes 2013;62:3418-3425.

109 Xiao L, Priest MF, Nasenbeny J, Lu T, Kozorovitskiy Y: Biased oxytocinergic modulation of midbrain dopamine systems. Neuron 2017;95:368-384.e5.
110 Herisson FM, Waas JR, Fredriksson R, Schiöth HB, Levine AS, Olszewski PK: Oxytocin acting in the nucleus accumbens core decreases food intake. J Neuroendocrinol 2016;28, DOI: 10.1111/jne.12381.

111 Cox BM, Bentzley BS, Regen-Tuero H, See RE, Reichel CM, Aston-Jones G: Oxytocin acts in nucleus accumbens to attenuate methamphetamine seeking and demand. Biol Psychiatry 2017;81:949-958.

112 Dölen G, Darvishzadeh A, Huang KW, Malenka RC: Social reward requires coordinated activity of nucleus accumbens oxytocin and serotonin. Nature 2013;501:179-184.

113 Kohno D, Nakata M, Maejima Y, Shimizu H, Sedbazar U, Yoshida N, Dezaki K, Onaka T, Mori M, Yada T: Nesfatin-1 neurons in paraventricular and supraoptic nuclei of the rat hypothalamus coexpress oxytocin and vasopressin and are activated by refeeding. Endocrinology 2008;149:1295-1301.

114 Singru PS, Sánchez E, Fekete C, Lechan RM: Importance of melanocortin signaling in refeeding-induced neuronal activation and satiety. Endocrinology 2007;148:638-646.

115 Bisset GW, Errington ML, Richards CD: The distribution of vasopressin and oxytocin in the hypothalamoneurohypophysial system of the guinea-pig. Br J Pharmacol 1973;48: 263-272.

116 Hara Y, Ueta Y, Isse T, Serino R, Shibuya I, Hattori Y, Yamashita $\mathrm{H}$ : Increase of urocortin-like immunoreactivity in the supraoptic nucleus of Dahl rats given a high salt diet. Neurosci Lett 2000;279:17-20.

117 Naïmi N, Rivest S, Racotta I, Richard D: Neuronal activation of the hypothalamic magnocellular system in response to oropharyngeal stimuli in the rat. J Neuroendocrinol 1997;9:329-340.

118 Vacher CM, Frétier P, Créminon C, Calas A, Hardin-Pouzet $\mathrm{H}$ : Activation by serotonin and noradrenaline of vasopressin and oxytocin expression in the mouse paraventricular and supraoptic nuclei. J Neurosci 2002;22: 1513-1522.

119 Song Z, Levin BE, Stevens W, Sladek CD: Supraoptic oxytocin and vasopressin neurons function as glucose and metabolic sensors. Am J Physiol Regul Integr Comp Physiol 2014;306:R447-R456.

120 Sabatier N, Caquineau C, Dayanithi G, Bull P, Douglas AJ, Guan XM, Jiang M, Van der Ploeg L, Leng G: Alpha-melanocyte-stimulating hormone stimulates oxytocin release from the dendrites of hypothalamic neurons while inhibiting oxytocin release from their terminals in the neurohypophysis. J Neurosci 2003;23:10351-10358.

121 Cui LN, Saeb-Parsy K, Dyball RE: Neurones in the supraoptic nucleus of the rat are regulated by a projection from the suprachiasmatic nucleus. J Physiol 1997;502:149-159.

122 Sgro S, Ferguson AV, Renaud LP: Subfornical organ - supraoptic nucleus connections: an electrophysiologic study in the rat. Brain Res 1984;303:7-13.
123 Rilling JK, Young LJ: The biology of mammalian parenting and its effect on offspring social development. Science 2014;345:771776.

124 Jones C, Barrera I, Brothers S, Ring R, Wahlestedt C: Oxytocin and social functioning. Dialogues Clin Neurosci 2017;19:193201.

125 Veening JG, Olivier B: Intranasal administration of oxytocin: behavioral and clinical effects, a review. Neurosci Biobehav Rev 2013;37:1445-1465.

126 Young LJ, Barrett CE: Neuroscience. Can oxytocin treat autism? Science 2015;347: 825-826.

127 Leng G, Ludwig M: Intranasal oxytocin myths and delusions. Biol Psychiatry 2016; 79:243-250.

128 Iwasaki Y, Maejima Y, Suyama S, Yoshida M, Arai T, Katsurada K, Kumari P, Nakabayashi H, Kakei M, Yada T: Peripheral oxytocin activates vagal afferent neurons to suppress feeding in normal and leptin-resistant mice: a route for ameliorating hyperphagia and obesity. Am J Physiol Regul Integr Comp Physiol 2015;308:R360-R369.

129 Welch MG, Tamir H, Gross KJ, Chen J, Anwar M, Gershon MD: Expression and developmental regulation of oxytocin (OT) and oxytocin receptors (OTR) in the enteric nervous system (ENS) and intestinal epithelium. J Comp Neurol 2009;512:256-270.

130 Garrido-Urbani S, Deblon N, Poher AL, Caillon A, Ropraz P, Rohner-Jeanrenaud F, Altirriba J: Inhibitory role of oxytocin on TNFa expression assessed in vitro and in vivo. Diabetes Metab DOI: 10.1016/j.diabet.2017.10.004.

131 Plante E, Menaouar A, Danalache BA, Yip D, Broderick TL, Chiasson JL, Jankowski M, Gutkowska J: Oxytocin treatment prevents the cardiomyopathy observed in obese diabetic male db/db mice. Endocrinology 2015; 156:1416-1428.

132 Durham DA, Banks WA, Kastin AJ: Carriermediated transport of labeled oxytocin from brain to blood. Neuroendocrinology 1991; 53:447-452.

133 Mens WB, Witter A, van Wimersma Greidanus TB: Penetration of neurohypophyseal hormones from plasma into cerebrospinal fluid (CSF): half-times of disappearance of these neuropeptides from CSF. Brain Res 1983;262:143-149.

134 Lee MR, Scheidweiler KB, Diao XX, Akhlaghi F, Cummins A, Huestis MA, Leggio L, Averbeck BB: Oxytocin by intranasal and intravenous routes reaches the cerebrospinal fluid in rhesus macaques: determination using a novel oxytocin assay. Mol Psychiatry 2018; 23:115-122.

135 Noble EE, Billington CJ, Kotz CM, Wang C: Oxytocin in the ventromedial hypothalamic nucleus reduces feeding and acutely increases energy expenditure. Am J Physiol Regul Integr Comp Physiol 2014;307:R737-R745.
Anorexigenic Oxytocin and Clinical Implications
Neuroendocrinology 2018;107:91-104 DOI: $10.1159 / 000489263$ 
136 Eckertova M, Ondrejcakova M, Krskova K, Zorad S, Jezova D: Subchronic treatment of rats with oxytocin results in improved adipocyte differentiation and increased gene expression of factors involved in adipogenesis. Br J Pharmacol 2011;162:452-463.

137 Balazova L, Krskova K, Suski M, Sisovsky V, Hlavacova N, Olszanecki R, Jezova D, Zorad S: Metabolic effects of subchronic peripheral oxytocin administration in lean and obese Zucker rats. J Physiol Pharmacol 2016;67: 531-541.

138 Qian W, Zhu T, Tang B, Yu S, Hu H, Sun W, Pan R, Wang J, Wang D, Yang L, Mao C, Zhou L, Yuan G: Decreased circulating levels of oxytocin in obesity and newly diagnosed type 2 diabetic patients. J Clin Endocrinol Metab 2014;99:4683-4689.
139 Yuan G, Qian W, Pan R, Jia J, Jiang D, Yang Q, Wang S, Liu Y, Yu S, Hu H, Sun W, Ye J, Mao C, Zhuang R, Zhou L: Reduced circulating oxytocin and high-molecular-weight adiponectin are risk factors for metabolic syndrome. Endocr J 2016;63:655-662.

140 Watanabe S, Wei FY, Matsunaga T, Matsunaga N, Kaitsuka T, Tomizawa K: Oxytocin protects against stress-induced cell death in murine pancreatic $\beta$-cells. Sci Rep 2016;6: 25185.

141 Benelli A, Bertolini A, Arletti R: Oxytocininduced inhibition of feeding and drinking: no sexual dimorphism in rats. Neuropeptides 1991;20:57-62.

142 Zhang H, Wu C, Chen Q, Chen X, Xu Z, Wu J, Cai D: Treatment of obesity and diabetes using oxytocin or analogs in patients and mouse models. PLoS One 2013;8:e61477.
143 Elabd SK, Sabry I, Mohasseb M, Algendy A: Oxytocin as a novel therapeutic option for type I diabetes and diabetic osteopathy. Endocr Regul 2014;48:87-102.

144 Einfeld SL, Smith E, McGregor IS, Steinbeck K, Taffe J, Rice LJ, Horstead SK, Rogers N, Hodge MA, Guastella AJ: A double-blind randomized controlled trial of oxytocin nasal spray in Prader Willi syndrome. Am J Med Genet A 2014;164A:2232-2239.

145 Higashida H, Furuhara K, Yamauchi AM Deguchi K, Harashima A, Munesue S, Lopatina O, Gerasimenko M, Salmina AB, Zhang JS, Kodama H, Kuroda H, Tsuji C, Suto S, Yamamoto H, Yamamoto Y: Intestinal transepithelial permeability of oxytocin into the blood is dependent on the receptor for advanced glycation end products in mice. Sci Rep 2017;7:7883. 